\title{
Study on Treatment of Anaerobic Fermentation Liquid by A2N Denitrification and Phosphorus Removal System
}

\author{
Andong $\mathrm{Ge}^{\text {a }}$, Qiong Jin, Lan Ma \\ Shenyang Urban Planning Design and Research Institute, Liaoning 110168, China \\ a316500619@qq.com
}

Keywords: Double sludge system, DPB, Low C / N ratio, anaerobic fermentation liquid.

\begin{abstract}
A2N (anaerobic / anoxic and nitrification) denitrifying phosphorus and nitrogen removal process is a new process which based on denitrifying PAOs anoxic phosphorus theory. The experiment used the continuous flow $\mathrm{A} 2 \mathrm{~N}$ system for dealing with the dilution of high concentration of anaerobic fermentation slurry. The average removal rate of COD is $91.02 \%$; the average total removal rate of ammonia nitrogen is $91 \%$, Removal rate of TP is $95 \%$. So the system has better treatment effect for low carbon and nitrogen ratio sewage.
\end{abstract}

\section{Introduction}

With the eutrophication of water is becoming increasingly serious, the state launched ten water policy, and gradually improved sewage treatment standards. Because the city sewage $\mathrm{C} / \mathrm{N}$ is generally low, which is not conducive to the efficient removal of nitrogen and phosphorus, but in this case the DPB can effectively remove nitrogen and phosphorus in water. The hydrolysis of intracellular DPB in the anaerobic environment of phosphorus, phosphate release into the mixture, while absorbing organic sewage in a large number of easily biodegradable $\mathrm{COD}_{\mathrm{RB}}$ and converted into PHB stored in DPB, In hypoxia, DPB use PHB as electron donor, with $\mathrm{NO}_{3}{ }^{-}-\mathrm{N}$ as the electron acceptor, produced by degradation of $\mathrm{PHB}$, for maintaining the life of most cells. A part is used for the excessive intake of inorganic phosphate in the form of Poly-p stored in the cell, while $\mathrm{NO}_{3}{ }^{-}-\mathrm{N}$ is reduced to $\mathrm{N}_{2}{ }^{[1-4]}$. Compared with the traditional biological nitrogen and phosphorus removal technology, this technology can save the carbon source, aeration, discharge of sludge reduction.

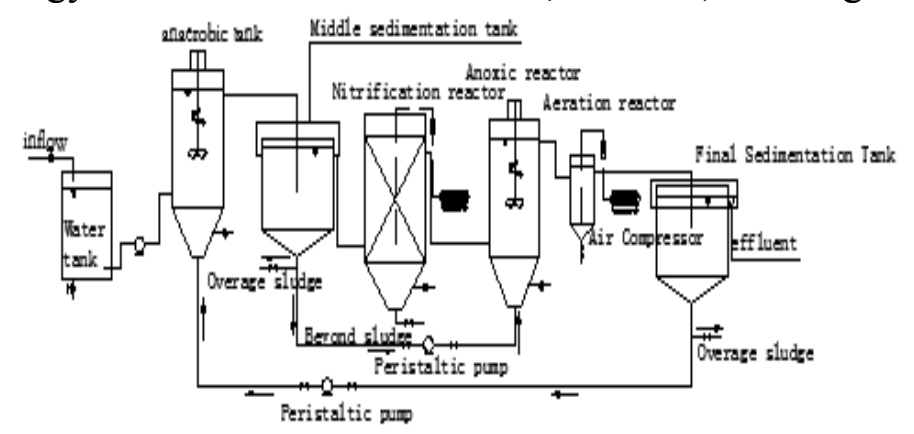

Fig.1 Process of A2N

\section{Experimental equipment and sludge sources}

The experiment device of $\mathrm{A}_{2} \mathrm{~N}$ system is made of plexiglass, including anaerobic reactor, biofilm reactor, anoxic reactor, fast aeration reactor and two Sedimentation tank. DPB and nitrifying bacteria were cultured separately.

\section{Results and discussion}

\subsection{Removal effect of COD.}

The removal of organism is an important index to measure the process efficiency, $\mathrm{A}_{2} \mathrm{~N}$ system takes COD as the main organic matter. Fig. 2 expresses the system's removal of COD,Fig. 3 expresses 
the average concentration of COD in different reaction stages. The influent COD concentration of the system is $254.83 \sim 327.34 \mathrm{mg} / \mathrm{L}$, The average concentration of the influent is $279.28 \mathrm{mg} / \mathrm{L}$, the average effluent concentration is $25.23 \mathrm{mg} / \mathrm{L}$, The average removal rate of COD is $91.02 \mathrm{mg} / \mathrm{L}$, it shows that the removal of COD is stable and efficient. From Fig.2 and Fig.3, it can be seen that the removal of COD is achieved by anaerobic process. The average removal rate of COD is $68.37 \%$. In addition to the anoxic tank of COD with beyond sludge and the dilution effect of the backflow sludge, the main reason is in the process of anaerobic environment, DPB releases phosphorus, absorps and converts COD to PHB, so the COD can be greatly reduced. After the membrane bioreactor, the concentration of COD Further decreased. In anoxic stage, the decrease of the amplitude is small, Even concentration rised, this is because a small amount of denitrification bacteria used the external carbon source fo denitrification, showing a decrease in COD concentration. The reason of the increase of COD is the inflowing of COD in beyong sludge.
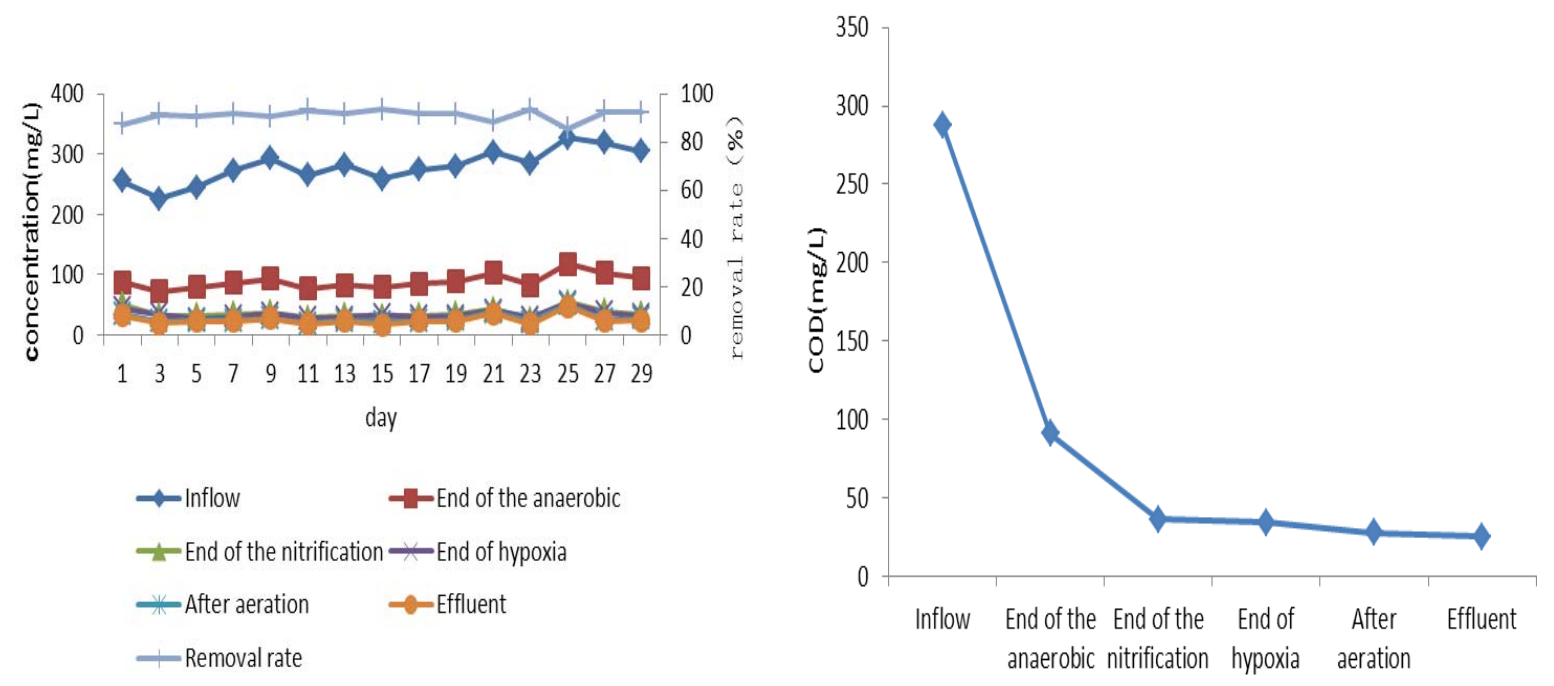

Fig.2 The COD removal efficiency

Fig.3 Variation of average COD concentration
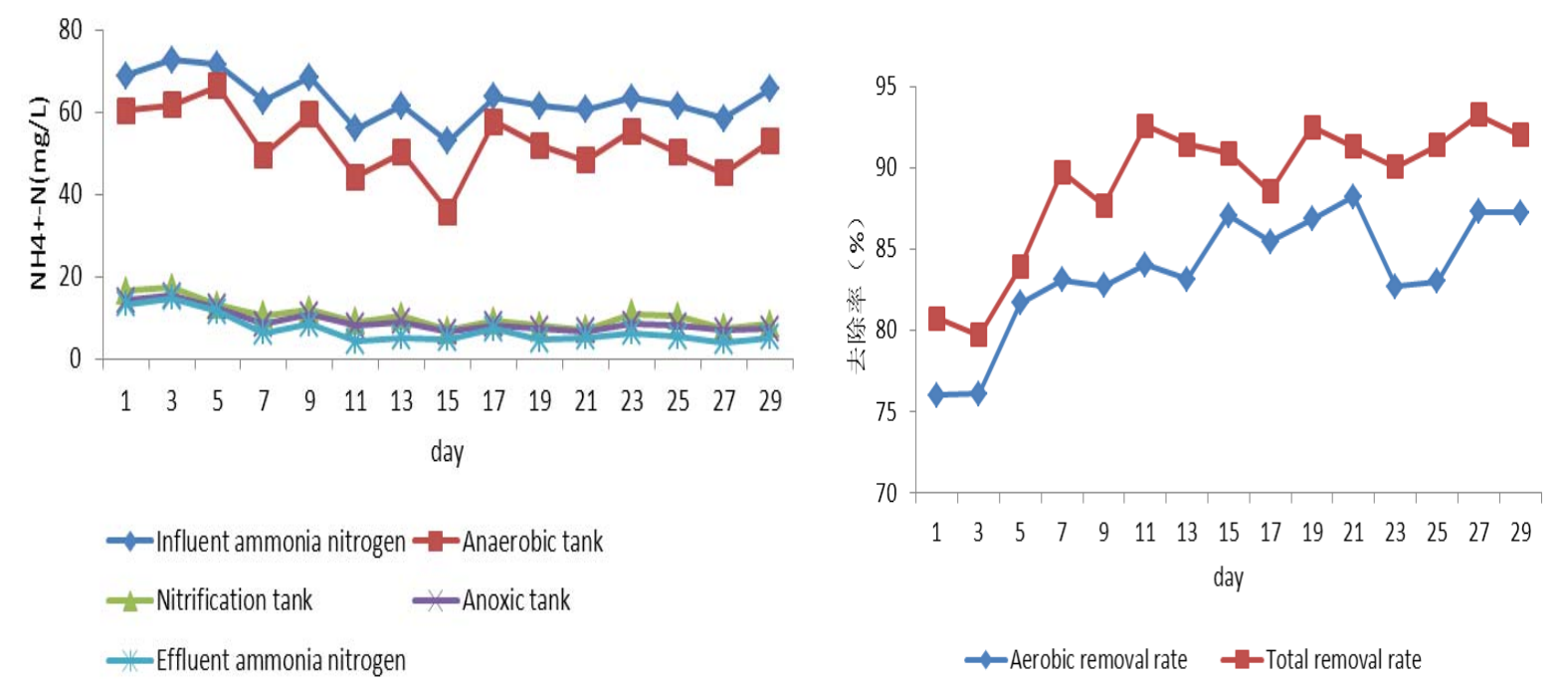

Fig. 4 NH4+-N concentration at different stages in the system Fig. 5 removal efficiency of NH4+-N

\subsection{Removal effect of ammonia nitrogen}

The ammonia nitrogen removal process of $\mathrm{A}_{2} \mathrm{~N}$ is in Fig. 4 and Fig.5. The figures can be seen after the anaerobic tank, part of the ammonia nitrogen removes with the assimilation of microorganisms, part for the sludge return function. Therefore, the concentration of ammonia nitrogen in the anaerobic effluent has a certain rise, and the most important role is return sludge. The concentration of ammonia nitrogen is greatly reduced, after nitrification tank, the average removal rate is $83.6 \%$, and then into 
the anoxic tank and fast aeration stage, part of ammonia is removed, the average concentration is 7.11 $\mathrm{mg} / \mathrm{L}$, the average of total removal rate of ammonia nitrogen is $91 \%$. Because the existence of the beyond sludge, the partial ammonia nitrogen enters into the anoxic tank with the sludge, leading to the increase of the concentration of ammonia nitrogen in the effluent, so the hydraulic residence time of the fast aeration tank should be appropriately increased. Effluent ammonia nitrogen concentration is one of the shortcomings of the denitrification and phosphorus removal system.

\subsection{Removal effect of $T N$}

The $\mathrm{TN}$ of $\mathrm{A}_{2} \mathrm{~N}$ removal process is in Fig.6 and Fig7.Influent TN concentration is between the $62.95 \sim 82.54 \mathrm{mg} / \mathrm{L}$, effluent $\mathrm{TN}$ concentration is between the $33.36 \sim 9.03 \mathrm{mg} / \mathrm{L}$, and effluent $\mathrm{TN}$ concentration gradually becomes small, effluent concentration reduced to below $10 \mathrm{mg} / \mathrm{L}$ on the $27^{\text {th }}$ and $29^{\text {th }}$ day, TN removal rate of the system reaches more than $85 \%$. TN in Sewage is mainly composed of ammonia nitrogen and organic nitrogen, after nitrification and anaerobic, TN decreases little. This is mainly microbial assimilation and nitrification tank biofilm has weak denitrification capacity. The TN removal is mainly in the anoxic tank. DPB uses PHB as electron donor, uses nitrate as electron acceptor, the nitrate nitrogen is converted to $\mathrm{N}_{2}$, finishing the removal of nitrogen and phosphorus, the average removal rate of $\mathrm{TN}$ in the process is about $75 \%$. However, due to the effect of partial ammonia nitrogen in the beyong sludge, the removal of ammonia nitrogen by rapid aeration tank is not Satisfying, so the removal of TN is not enough.

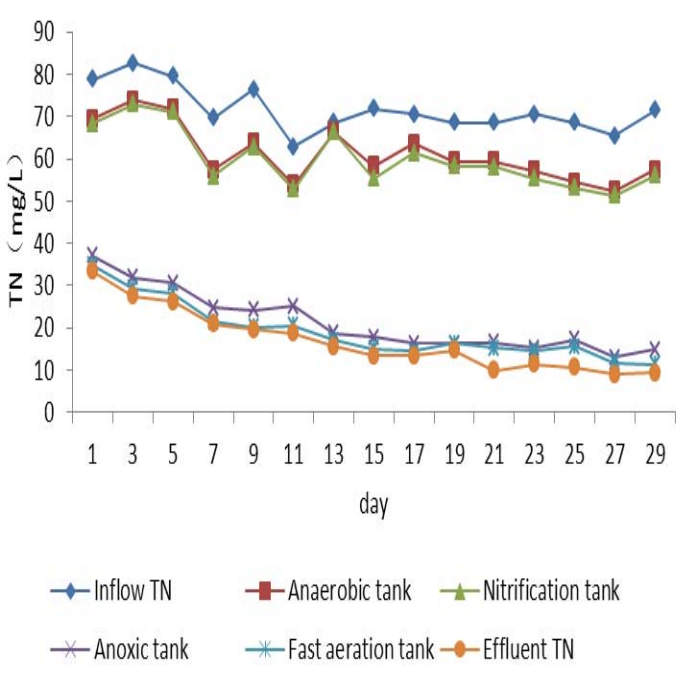

Fig. $6 \mathrm{TN}$ concentration at different stages

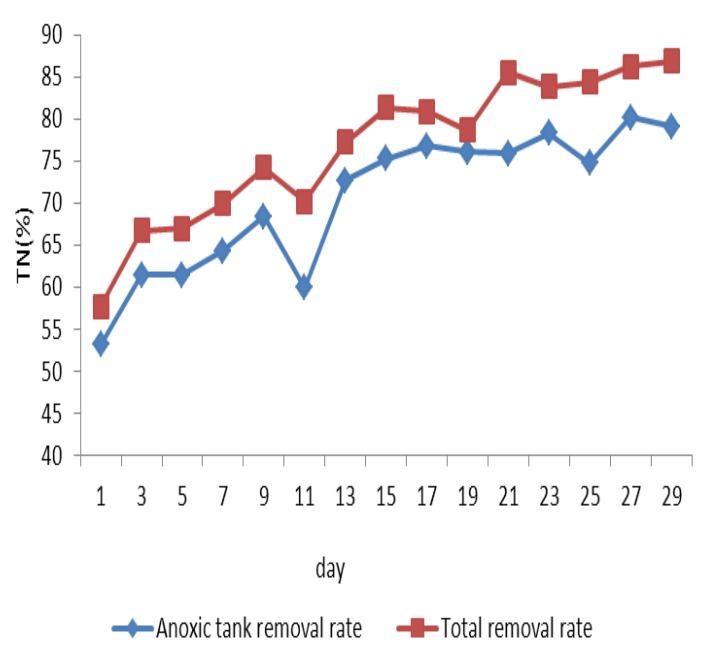

Fig.7 The removal efficiency of TN

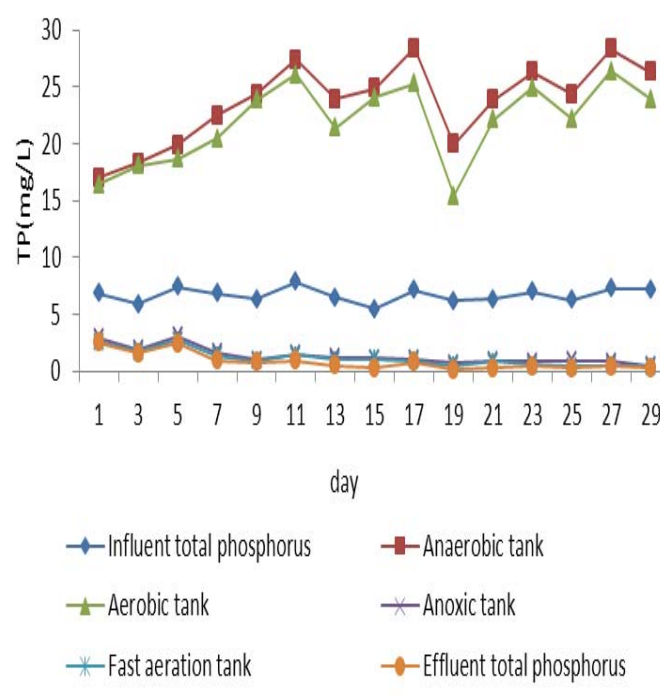

Figure $8 \mathrm{TP}$ concentration at different stages 


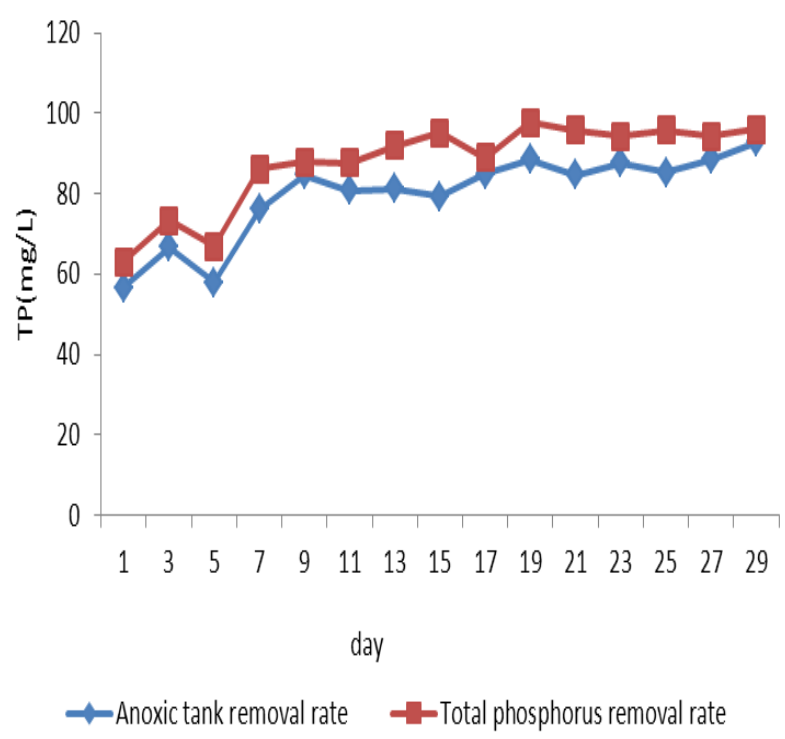

\subsection{Removal effect of TP}

Figure 9 The removal efficiency of TP

The TP of $\mathrm{A}_{2} \mathrm{~N}$ removal process is in Fig. 8 and Fig9, which can be seen within the first few days of the start-up phase, the TP removal rate is not stable. After the adaptation to the load of microorganism, removal rate is increased gradually, TP removal rate is maintained at $95 \%$ in the final days, and effluent TP concentration is below $0.5 \mathrm{mg} / \mathrm{l}$. It can be seen from the figures that the TP removal is mainly in the anoxic tank and few in the fast aeration tank and the nitrification tank. Effluent TP concentration appears some fluctuations,, the reason may is the anaerobic tank sludge contains too much oxidized nitrogen, which influences the system releasing effect of phosphorus in the anaerobic period, DPB cannot fully release phosphorus.

\section{Summary}

The system continuously runned for 31 days, the $\mathrm{A}_{2} \mathrm{~N}$ system has better treatment effect for low carbon nitrogen ratio of sewage. The influent COD concentration is $254.83 \sim 327.34 \mathrm{mg} / \mathrm{L}$, the average effluent concentration is $25.23 \mathrm{mg} / \mathrm{L}$, the average COD removal rate is $91.02 \mathrm{mg} / \mathrm{L}$, which shows the DPB has stable removal rate of COD. The ammonia nitrogen average removal rate is $91 \%$; $\mathrm{TN}$ concentration is between $62.95 \sim 82.54 \mathrm{mg} / \mathrm{L}$, effluent in the last stage is below $10 \mathrm{mg} / \mathrm{L}$, removal rate reaches more than $85 \%$; influent TP concentration is $632 \sim 9.23 \mathrm{mg} / \mathrm{L}$, TP removal rate remains at $95 \%$, effluent TP concentration is below $0.5 \mathrm{mg} / \mathrm{L}$.

\section{References}

[1]. Shuyan Tian, Jingfeng Wang, et al. Relationship between PHB and Polyphosphate under Anaerobic Condition and Related Biochemical Mechanisms[J].China Water\&Wastewater 2000,16(7):5-7.

[2]. Soejima K, Matsumoto S,et al. Modeling and experimental study on the anaerobic /aerobic /anoxic process for simultaneous nitrogen and phosphorus removal: the effect of acetate addition[J].Process Bilchemistry,2008,43(6):605-614.

[3]. Yang S, Yang F L, et al. Simultaneous nitrogen and phosphorus removal by a novel sequencing batch moving bed membrane bilreactor fof wastewater treatment[J].Journal of Hazardous Matenals,2010,175(1-3):551-557.

[4]. Yunfang Ling,Shuying Wang,et al.Analysis on influencing factors of A2N denitrifying phosphorus and nitrogen removal process[J].INDUSTRIAL WATER\& WASTEWATER, 2006. 37 (2):7-11. 